\title{
Influence of a carp invasion on the zooplankton community in Laguna Medina, a Mediterranean shallow lake
}

\author{
Norbert Florian ${ }^{1}$, Raquel Lopez-Luque ${ }^{2}$, Natalia Ospina-Alvarez ${ }^{2,4}$, Levente Hufnagel ${ }^{3}$ and \\ Andy J. Green ${ }^{2, *}$
}

${ }^{1}$ Department of Biometrics and Agroinformatics, Corvinus University of Budapest, Villányi út 29-43, 1118 Budapest, Hungary.

${ }^{2}$ Department of Wetland Ecology, Estación Biológica de Doñana-CSIC, Avda. Americo Vespucio s/n, 41092 Sevilla, Spain.

${ }^{3}$ Institute of Crop Production, Laboratory of Biometrics and Quantitative Ecology, Faculty of Agricultural and Environmental Sciences, Szent István University, Páter Károly utca 1, 2100 Gödöllő, Hungary.

${ }^{4}$ Institute of Earth and Environmental Sciences, Universität Potsdam, 14476 Potsdam, Germany.

* Corresponding author: ajgreen@ebd.csic.es

Received: $12 / 01 / 2016$

Accepted: 28/09/2016

\begin{abstract}
Influence of a carp invasion on the zooplankton community in Laguna Medina, a Mediterranean shallow lake

The common carp (Cyprinus carpio) is a highly invasive species and an ecological engineer. It has been repeatedly shown to increase nutrient concentrations and phytoplankton biomass while destroying submerged macrophytes, although there are few studies from the Mediterranean region. We studied its impact on the zooplankton community in Laguna de Medina lake, a shallow lake in Jerez de la Frontera, south-west Spain. Carp were removed with rotenone in 2007 but returned in $2010-2011$. We compared zooplankton sampled monthly from 8 points from May to December in 2008 (without carp) and 2012 (with carp). Extensive macrophyte beds present in 2008 were absent in 2012. As expected, chlorophyll- $a$ concentrations, turbidity, total suspended solids and total phosphorus were much higher in 2012. Zooplankton richness decreased from 21 taxa in 2008 to 8 taxa in 2012, accompanied by a decrease in Shannon-Wiener diversity, an increase in Evenness and a change in size distribution with loss of larger taxa. In 2008, the crustaceans were dominated by the macrocladocerans Daphnia magna and Moina brachiata and the large calanoid copepod Arctodiaptomus salinus. In 2012, these three taxa were completely absent and the zooplankton was dominated by the alien cyclopoid Acanthocyclops americanus and the rotifers Brachionus plicatilis and Keratella quadrata. Our results confirm the disappearance of macrocladocera reported by others in mesocosm experiments with carp, and suggest that alien carp facilitate the spread of the alien copepod A. americanus.
\end{abstract}

Key words: Acanthocyclops, biomanipulation, Cladocera, invasive species, Mediterranean shallow lake.

\section{RESUMEN}

Influencia de la invasión de carpa en la comunidad de zooplancton en la Laguna Medina, un lago somero Mediterráneo

La carpa común (Cyprinus carpio) es una especie altamente invasora y actúa como un ingeniero ecológico en el ecosistema. Se ha demostrado en repetidas ocasiones que aumenta las concentraciones de nutrientes y biomasa del fitoplancton mientras destruye macrófitas sumergidas, aunque hay pocos estudios de la región mediterránea. En este estudio se investigó el impacto de la carpa sobre la comunidad de zooplancton en Laguna de Medina, un lago somero de Jerez de la Frontera, suroeste de España. Las carpas fueron retiradas con rotenona en 2007, pero regresaron en 2010-2011. Se comparó el zooplancton muestreado mensualmente en 8 puntos de mayo a diciembre de 2008 (sin presencia de carpas) y en 2012 (con carpas). Superficies extensivas de macrófitas presentes en 2008 no fueron observadas en 2012. Como era esperado, la concentración de clorofila, turbiedad, sólidos suspendidos totales y el fósforo total fueron mucho más altos en 2012. La riqueza de zooplancton disminuyó de 21 taxones en 2008 a 8 taxones en 2012, acompañado por una disminución en el índice de diversidad de Shannon-Wiener, un aumento en la uniformidad y un cambio en la distribución de tamaños con la pérdida de los taxones de mayor tamaño. En 2008, los crustáceos estaban dominados por los macrocladoceros Daphnia magna y Moina brachiata y el gran copépodo calanoide Arctodiaptomus salinus. En 2012, estos tres taxones estaban completamente ausentes y la 
comunidad estuvo dominada por los aciclopoides invasores Acanthocyclops americanus y los rotíferos Brachionus plicatilis $y$ Keratella quadrata. Nuestros resultados confirman la desaparición de macrocladoceros reportados por otros autores en experimentos de mesocosmos con carpas, y sugieren que la carpa invasora facilita la propagación del copépodo invasor A. americanus.

Palabras clave: Acanthocyclops, biomanipulación, Cladocera, especies invasoras, lagos someros mediterráneos.

\section{INTRODUCTION}

The common carp (Cyprinus carpio) is widely distributed as an alien species and is considered one of the world's worst invasive species (www. iucngisd.org) because it has a major impact on aquatic ecosystems. It has strong direct effects on the communities of aquatic invertebrates, fish and waterbirds through predation or competition (Weber \& Brown, 2009). In addition, carp are ecosystem engineers causing bioturbation and high turbidity through their feeding behaviour (Bajer et al., 2009; Kloskowski, 2011). By increasing turbidity and direct consumption, carp reduce the cover of submerged vegetation and promote a shift from a clear- to turbid-state in shallow lakes and a resulting reduction in biodiversity (Bajer et al., 2009). Removal of carp in biomanipulations typically results in a recovery of macrophytes together with a drop in turbidity, nutrient concentrations and phytoplankton biomass (Bajer et al., 2015).

Carp are omnivorous, feeding largely on macrophytes and invertebrates, and up to $25 \%$ of the biomass ingested consists of zooplankton (Meijer et al., 1990; Khan, 2003; Britton et al., 2007). Carp can therefore affect the zooplankton community in many ways, by direct predation (Miller \& Crowl, 2006), by consuming macroinvertebrates that themselves are zooplankton predators (Khan, 2003), through loss of macrophytes that provide shelter, and by increasing phytoplankton biomass and promoting cyanobacterial blooms (Parkos et al., 2003). Furthermore, resuspension of sediment particles can interfere with the filtering apparatus of cladocerans (Kirk \& Gilbert, 1990), and bioturbation may also affect the dormant stages in sediments, with negative effects on emergence patterns (Angeler et al., 2002).

In the Mediterranean region, the effects of carp appear to be stronger than in temperate latitudes because relatively high temperatures all year round increase the levels of fish activity. However, little information is available on how carp affect zooplankton in Mediterranean shallow lakes. Although mesocosm or enclosure experiments have demonstrated a strong impact of carp on zooplankton in semi-arid and temperate lakes (Angeler et al., 2002; Williams \& Moss, 2003), there is a need for whole lake studies to improve our understanding of their effects at the ecosystem scale.

The objective of the present work was to explore how zooplankton communities were changed by the reintroduction of carp into a Mediterranean shallow lake, and how this was related to changes in physico-chemical variables. Medina lake (120 ha) in southern Spain is a closed basin playa lake protected under the Ramsar Convention because of its importance for waterbirds, including the globally threatened whiteheaded duck Oxyura leucocephala. In 2003, carp entered the lake, leading to a crash in the numbers of waterbirds and a loss of submerged vegetation. In September 2007, carp were eradicated by the regional government using rotenone, with the objective of restoring values for waterbirds. This was initially successful, but carp re-entered the lake in 2010-2011 during extreme winter floods, causing a return to a state with no submerged vegetation and few birds. We studied the consequences for zooplankton and physico-chemical variables by intensive monitoring during two contrasting years: 2008 (without carp) and 2012 (with carp). We consider 
how the structure of the zooplankton community changed, how the diversity and species richness was affected, and how these changes were related to macrophyte cover, phytoplankton abundance and physico-chemical variables.

\section{MATERIAL AND METHODS}

\section{Study site}

Lake Medina (Fig. 1) is the third largest inland playa lake in Andalusia (de Vicente et al., 2012), located $30 \mathrm{~m}$ above sea level $\left(36^{\circ} 37^{\prime} 18^{\prime \prime} \mathrm{N}\right.$, $\left.6^{\circ} 02^{\prime} 48^{\prime \prime} \mathrm{W}\right)$. The average depth is $1 \mathrm{~m}$ and when the maximum depth reaches $3.5 \mathrm{~m}$ depth an artificial overflow prevents further filling (Rodríguez-Rodríguez et al., 2011). The lake is semipermanent and mesohaline with basic $\mathrm{pH}$ and high alkalinity (de Vicente et al., 2012), and was very important for waterbirds when carp were absent, i.e. before 2003 and from 2007 to 2010 (Amat, 1984; Martí \& del Moral, 2002; Martínez-Haro et al., 2011). The lake is polluted by spent lead shot that accumulated in the sediment prior to protection in 1987 (Mateo et al., 2007) and is surrounded by agricultural land that influences hydrology and nutrient loading (Rodríguez-Rodríguez, 2011). Although carp were totally eliminated from the lake in September 2007 (13 $416 \mathrm{~kg}$ of carp were removed), the alien eastern mosquito fish Gambusia holbrooki was not, and was abundant in the littoral zone of the lake during our "without carp" study year.

\section{Sampling Methods}

Sampling was carried out at eight different fixed sampling points around the lake (Fig. 1) on a monthly basis (except for the month of June) for the following periods: from January 2008 until December 2008 (without carp) and from May 2012 till December 2012 (with carp). Each point was positioned several metres away from the shoreline, marked with an iron stake, and positioned with a GPS. Sampling was conducted between the hours of 08:00 $\mathrm{h}$ and 13:00 $\mathrm{h}$.

The following environmental variables were taken in situ with a portable WTW 340I/SET: temperature $\left({ }^{\circ} \mathrm{C}\right), \mathrm{pH}$, conductivity $(\mu \mathrm{S} / \mathrm{cm})$ and dissolved oxygen $(\mathrm{mg} / \mathrm{l}$ or $\%)$. Several water samples were collected for laboratory analyses, as follows. Turbidity was measured with a Hanna instruments HI93703 meter and is expressed as NTU (Nephelometric Turbidity Units). Chloro-
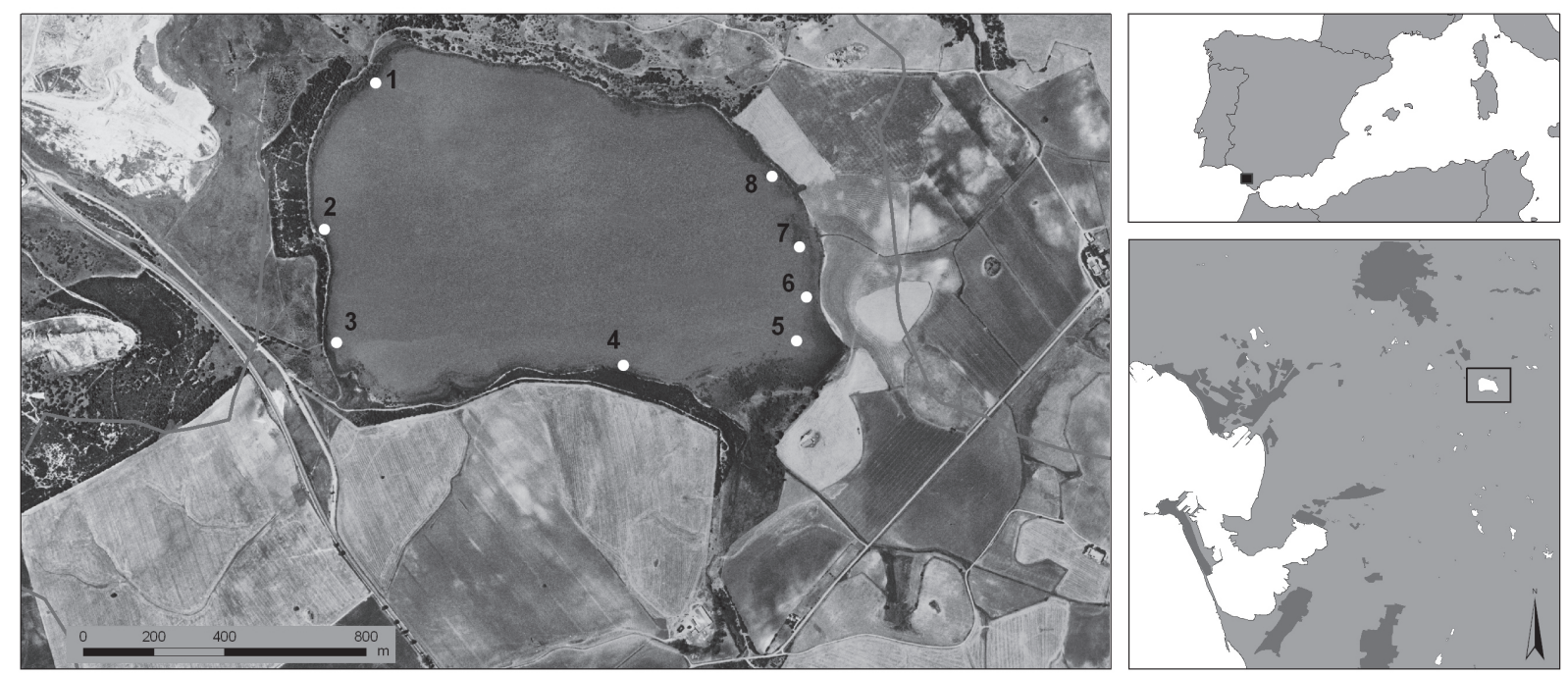

Figure 1. Geographic location of Medina lake (Cádiz. Spain). Circles indicate the eight sampling points. Localización geográfica de la laguna de Medina (Cádiz. España). Los círculos indican los ocho puntos de muestreo. 
phyll- $a$ was extracted with $90 \%$ acetone after filtering a known volume of lake water through a GF/F Whatman filter, and measured by spectophotometry using the trichromatic method (Jeffrey \& Humphrey, 1975). Total nitrogen concentration (Total N) was measured by digestion with potassium persulfate (Sims et al., 1995), and total phosphorus concentration (Total P) by the phosphomolybdate method (APHA, 1995). Total suspended solids (TSS) were determined following APHA (1995) by filtering a well-mixed water sample through a pre-weighed standard glass-fiber filter, then reweighing after drying to a constant weight at $105^{\circ} \mathrm{C}$. Dissolved nutrient concentrations (nitrates, nitrites, ammonium and phosphate) were measured in the filtrate after

Table 1. Summary of environmental variables in Medina lake in 2008 (without carp) and 2012 (with carp). Differences between years (from May to December) were tested with Wilcoxon matched-paired tests. N1: number of valid data, N2: number of matched pairs of data from the same point and same month, z: z-score is the normally distributed test value of Wilcoxon's rank test. Resumen de las variables ambientales en la laguna de Medina entre 2008 (sin carpas) y 2012 (con carpas). Las diferencias entre años (de mayo a diciembre) fueron evaluadas con un test de Wilcoxon para datos emparejados-pareados. N1: número de datos válidos, N2: número de parejas de datos para el mismo punto y el mismo mes, z: z es el valor de la prueba de distribución de normalidad en la prueba de rangos de Wilcoxon.

\begin{tabular}{|c|c|c|c|c|c|c|c|c|}
\hline Variable & Unit & Year & N1 & Mean & Standard deviation & $\mathrm{N} 2$ & $z$ & $p$ \\
\hline \multirow[t]{2}{*}{$\mathrm{pH}$} & & 2008 & 56 & 8.489 & 0.57 & 56 & 0.477 & 0.63323 \\
\hline & & 2012 & 56 & 8.489 & 0.29 & & & \\
\hline \multirow[t]{2}{*}{ Temperature } & ${ }^{\circ} \mathrm{C}$ & 2008 & 56 & 20.09 & 6.36 & 56 & 3.632 & $<0.001$ \\
\hline & & 2012 & 56 & 21.36 & 4.60 & & & \\
\hline \multirow[t]{2}{*}{ Conductivity } & $\mathrm{mS} / \mathrm{cm}$ & 2008 & 56 & 10.78 & 1.35 & 55 & 6.451 & $<0.0001$ \\
\hline & & 2012 & 55 & 6.51 & 0.78 & & & \\
\hline \multirow[t]{2}{*}{ Salinity } & $\mathrm{g} / \mathrm{L}$ & 2008 & 56 & 6.11 & 0.86 & 56 & 6.509 & $<0.0001$ \\
\hline & & 2012 & 56 & 3.53 & 0.49 & & & \\
\hline \multirow[t]{2}{*}{ Dissolved oxygen } & $\mathrm{mg} / \mathrm{L}$ & 2008 & 55 & 8.19 & 1.79 & 47 & 3.862 & $<0.001$ \\
\hline & & 2012 & 48 & 9.37 & 2.80 & & & \\
\hline \multirow[t]{2}{*}{ Depth } & $\mathrm{cm}$ & 2008 & 56 & 62.98 & 22.72 & 56 & 5.477 & $<0.0001$ \\
\hline & & 2012 & 56 & 85.40 & 35.12 & & & \\
\hline \multirow[t]{2}{*}{ Turbidity } & NTU & 2008 & 56 & 22.56 & 16.43 & 56 & 4.478 & $<0.0001$ \\
\hline & & 2012 & 56 & 35.07 & 21.86 & & & \\
\hline \multirow[t]{2}{*}{ Chlorophyll- $a$} & $\mu g / L$ & 2008 & 55 & 7.86 & 5.95 & 55 & 6.451 & $<0.0001$ \\
\hline & & 2012 & 56 & 100.97 & 65.88 & & & \\
\hline \multirow[t]{2}{*}{ Total N } & $\mathrm{mg} / \mathrm{L}$ & 2008 & 49 & 3.06 & 0.68 & 49 & 5.005 & $<0.0001$ \\
\hline & & 2012 & 56 & 2.46 & 0.65 & & & \\
\hline \multirow[t]{2}{*}{ Nitrite } & $\mathrm{mg} / \mathrm{L}$ & 2008 & 33 & 0.09 & 0.09 & 33 & 4.372 & $<0.0001$ \\
\hline & & 2012 & 54 & 0.02 & 0.04 & & & \\
\hline \multirow[t]{2}{*}{ Nitrate } & $\mathrm{mg} / \mathrm{L}$ & 2008 & 32 & 1.11 & 1.88 & 32 & 4.493 & $<0.0001$ \\
\hline & & 2012 & 56 & 0.02 & 0.04 & & & \\
\hline \multirow[t]{2}{*}{ Ammonium } & $\mathrm{mg} / \mathrm{L}$ & 2008 & 33 & 0.44 & 0.38 & 33 & 4.985 & $<0.0001$ \\
\hline & & 2012 & 56 & 0.01 & 0.02 & & & \\
\hline \multirow[t]{2}{*}{ Total P } & $\mathrm{mg} / \mathrm{L}$ & 2008 & 53 & 0.12 & 0.06 & 53 & 4.919 & $<0.0001$ \\
\hline & & 2012 & 56 & 0.19 & 0.07 & & & \\
\hline \multirow[t]{2}{*}{ Phosphate } & $\mathrm{mg} / \mathrm{L}$ & 2008 & 32 & 0.03 & 0.06 & 29 & 2.043 & $<0.05$ \\
\hline & & 2012 & 56 & 0.03 & 0.06 & & & \\
\hline \multirow[t]{2}{*}{ Total suspended solids } & $\mathrm{mg} / \mathrm{L}$ & 2008 & 56 & 48.01 & 27.53 & 56 & 3.789 & $<0.001$ \\
\hline & & 2012 & 56 & 120.31 & 235.28 & & & \\
\hline
\end{tabular}


lake water was passed through a standard glassfilter, using a SEAL Analytical AutoAnalyzer 3HR and a SYSTEA Micromac-1000. Usually this filtrate was frozen at $-20^{\circ} \mathrm{C}$ for some weeks prior to analysis.

Zooplankton were sampled using an acrylic tube sampler as used by Louette \& De Meester (2005) with a diameter of $8 \mathrm{~cm}$ and a length of $136 \mathrm{~cm}$, which allowed sampling of the entire water column. The tube was inserted vertically to a depth of $70 \mathrm{~cm}$ if the depth was sufficient at the fixed sampling point, or less if it was not. Samples were filtered in situ through a $64 \mu \mathrm{m}$ mesh Nytex screen and preserved in an iodine solution (Lugol).

All zooplankton individuals (including rotifers, copepods, cladocerans and ostracods) were counted and identified to species where possible. For counting, we used an inverted microscope at magnifications $10 \times$ and $20 \times$, and for detailed identification we used a light microscope at magnifications from $40 x$ to $100 x$. Taxa were identified using standard keys, including Dussart (1967, 1969), Flössner (2000), Einsele (1993), Gulyás \& Forró (1999, 2001) and Koste (1978). Mean length of each taxon was extracted from the literature. Juvenile stages of cladocerans and copepods could not be identified to species level. Samples with more than 1000 individuals were counted by subsampling. For cladocerans, copepods and ostracods we counted at least the $1 / 3$ of the sample, and for the smaller rotifers we counted at least $1 / 20^{\text {th }}$ of the sample.

\section{Remote sensing}

To assess submerged macrophyte vegetation cover at the water surface, we used Landsat L5TM data between 2008 and 2013. Satellite images were taken by the TM and ETM+ sensors on board the Landsat 5 and Landsat 7 satellites, obtained from the United States Geological Survey. We applied the Normalised Difference Vegetation Index (NDVI, Mather, 1987), which estimates the fraction of active photosynthetic radiation that is intercepted by vegetation (Alcaráz-Segura et al., 2009 and is based on the reflectance in the red (R) and near infrared (NIR) bands (bands 3 and 4, re- spectively, for Landsat images). Using ENVI 4.4 software, one mask was constructed for the total lake surface and a second mask for the vegetation cover. These masks were combined to obtain one that contained only aquatic vegetation. The mask area was quantified by the number of pixels ( $30 \mathrm{~m}$ $\times 30 \mathrm{~m}$ each).

\section{Data analysis}

Statistical analyses were performed with Past and STATISTICA (version 11; StatSoft, Tulsa, OK) software. Because many variables were not normally distributed, to compare the differences in environmental variables and in the abundance of taxa between the two years, we used nonparametric Wilcoxon matched-paired tests, pairing samples from the same points and months between years (e.g. pairing the sample from point 1 in May 2008 with that from point 1 in May 2012).

We quantified $\alpha$-diversities for each sample using the Shannon-Wiener index $\left(H^{\prime}\right)$, which takes into account the total number of taxa and their evenness (Magurran, 1988), and is relatively insensitive to the presence of rare species (Anderson, 1978). The Evenness index $(J)$ was used to measure the relative distribution of individual taxa (Krebs, 1989). When calculating the diversity measures, the copepod nauplii were assigned proportionally to the copepod species present in the sample.

For further analysis of relationships between the zooplankton community and environmental variables, we conducted a canonical correspondence analysis (CCA) to examine community composition patterns in the two years, and their relationship with nine environmental variables. The physical parameters (temperature, water depth, turbidity) and chemical data (conductivity, Total P, Total N, dissolved oxygen, chlorophyll- $a$ and TSS) formed one data matrix, and the second one included the abundance of zooplankton taxonomic groups. pH was excluded because there was no significant difference in this parameter between the two years (see below). All variables were $\log (x+1)$ transformed. Permutation tests $(n=999)$ identified the significance of the CCA axes. 


\section{RESULTS}

\section{Changes in environmental variables}

With the exception of $\mathrm{pH}$, all variables differed significantly between 2008 without carp and 2012 with carp (Table 1). The water level in the lake was generally higher in 2012, leading to an increased depth and decreased salinity and conductivity. Temperature, dissolved oxygen, chlorophyll- $a$, Total $\mathrm{P}$, turbidity and total suspended solids (TSS) were all higher in 2012, the increases in chlorophyll- $a$ and turbidity being particularly consistent (Table 1, Fig. 2). In contrast, Total N, nitrite, nitrate, phosphate and ammonium concentrations were all significantly lower in 2012 (Table 1). The temperature range recorded for the whole study was from $11.3{ }^{\circ} \mathrm{C}$ to $30.1{ }^{\circ} \mathrm{C}$.

\section{Changes in zooplankton taxonomic composition}

In Medina lake we found 21 zooplankton taxa in 2008 (without carp), but only 8 taxa were found in 2012 (with carp, Table 2). When considering

Table 2. Abundance of zooplankton taxa in 2008 (without carp) and 2012 (with carp). Differences between years were tested with Wilcoxon matched-paired tests, with $\mathrm{N}$ pairs of data from the same point and same month (May to December). $P$ values are given in italics for the only two taxa for which the difference between years was not statistically significant. Two additional Copepoda were recorded in January-April 2008 (Diacyclops bisetosus and Paracyclops fimbriatus, one individual of each). Abundancia de los diferentes taxones de zooplancton en 2008 (sin carpas) y 2012 (con carpas). Las diferencias entre años fueron evaluadas con un test de Wilcoxon para datos emparejados-pareados, con $N$ pares de datos para el mismo punto y en el mismo mes (mayo a diciembre). Los valores $\mathrm{P}$ son presentados en letras cursivas para los dos únicos taxones para los cuales la diferencia entre años no fue estadísticamente significativa. Dos copépodos adicionales fueron registrados en abril-enero de 2008 (Diacyclops bisetosus y Paracyclops fimbriatus, un individuo de cada uno).

\begin{tabular}{|c|c|c|c|c|c|c|c|c|c|c|c|}
\hline & \multicolumn{4}{|c|}{2008} & \multicolumn{5}{|c|}{2012} & \multirow[b]{2}{*}{$z$} & \multirow[b]{2}{*}{$p$} \\
\hline & sum & median & $\min$ & $\max$ & sum & median & $\min$ & $\max$ & $\mathrm{N}$ & & \\
\hline \multicolumn{12}{|l|}{ CLADOCERA } \\
\hline Alona rectangula & 146 & 0 & 0 & 39 & 12 & 0 & 0 & 6 & 51 & 3.753 & $<0.001$ \\
\hline Chydorus pizarri & 0 & 0 & 0 & 0 & 1 & 0 & 0 & 1 & - & - & - \\
\hline Daphnia magna & 4065 & 6 & 0 & 704 & 0 & 0 & 0 & 0 & 51 & 4.703 & $<0.0001$ \\
\hline Diaphanosoma brachyura & 353 & 0 & 0 & 215 & 0 & 0 & 0 & 0 & 51 & 3.296 & $<0.001$ \\
\hline Dunhevedia crassa & 120 & 0 & 0 & 56 & 0 & 0 & 0 & 0 & 51 & 3.724 & $<0.001$ \\
\hline Moina brachiata & 2020 & 0 & 0 & 513 & 0 & 0 & 0 & 0 & 51 & 2.803 & 0.0051 \\
\hline Oxyurella tenicaudis & 0 & 0 & 0 & 0 & 58 & 0 & 0 & 44 & 51 & 1.826 & 0.0679 \\
\hline \multicolumn{12}{|l|}{ COPEPODA } \\
\hline Acanthocyclops americanus & 33 & 0 & 0 & 12 & 77328 & 700 & 18 & 10260 & 51 & 6.215 & $<0.0001$ \\
\hline Arctodiaptomus salinus & 43698 & 640 & 4 & 3542 & 0 & 0 & 0 & 0 & 51 & 6.215 & $<0.0001$ \\
\hline Cyclops strenuus & 5 & 0 & 0 & 2 & 0 & 0 & 0 & 0 & - & - & - \\
\hline Megacyclops viridis & 36 & 0 & 0 & 10 & 0 & 0 & 0 & 0 & 51 & 3.296 & $<0.001$ \\
\hline nauplii & 34106 & 252 & 0 & 4558 & 20010 & 351 & 11 & 1944 & 51 & 0.455 & 0.6494 \\
\hline \multicolumn{12}{|l|}{ ROTIFERA } \\
\hline Asplachna quadridentatus & 47 & 0 & 0 & 10 & 0 & 0 & 0 & 0 & 51 & 2.934 & $<0.05$ \\
\hline Brachionus novae-zelandie & 4060 & 0 & 0 & 1894 & 0 & 0 & 0 & 0 & 51 & 4.107 & $<0.0001$ \\
\hline Brachionus plicatilis & 23556 & 1 & 0 & 4104 & 325895 & 1766 & 0 & 93330 & 51 & 5.268 & $<0.0001$ \\
\hline Brachionus quadridentatus & 211 & 0 & 0 & 86 & 0 & 0 & 0 & 0 & 51 & 2.934 & $<0.005$ \\
\hline Encentrum sp. & 14 & 0 & 0 & 14 & 0 & 0 & 0 & 0 & - & - & - \\
\hline Hexarthra fennica & 2494 & 0 & 0 & 708 & 1 & 0 & 0 & 1 & 51 & 2.801 & 0.0051 \\
\hline Keratella quadrata & 305 & 0 & 0 & 305 & 1521155 & 0 & 0 & 304000 & 51 & 4.157 & $<0.0001$ \\
\hline Lecane lamellata & 213 & 0 & 0 & 64 & 0 & 0 & 0 & 0 & 51 & 3.516 & $<0.001$ \\
\hline Testudinella patina & 30 & 0 & 0 & 25 & 0 & 0 & 0 & 0 & 51 & 2.201 & $<0.05$ \\
\hline OSTRACODA & 3734 & 17 & 0 & 714 & 117 & 0 & 0 & 74 & 51 & 5.536 & $<0.0001$ \\
\hline
\end{tabular}


a)

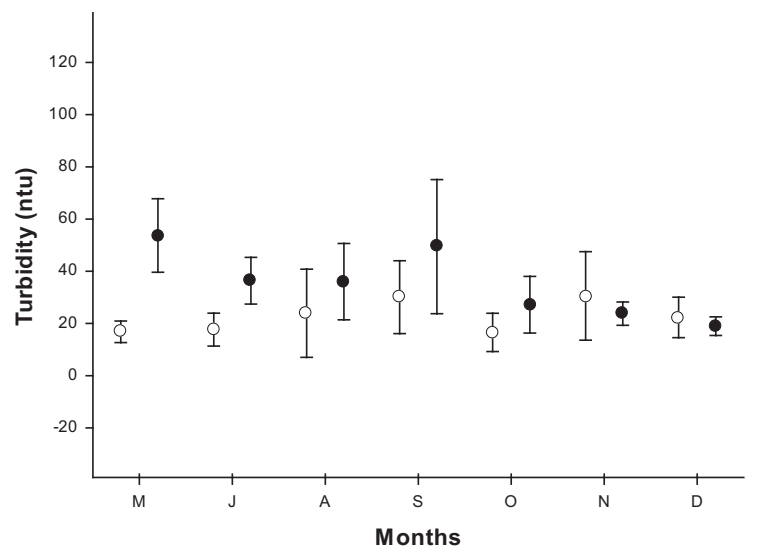

b)

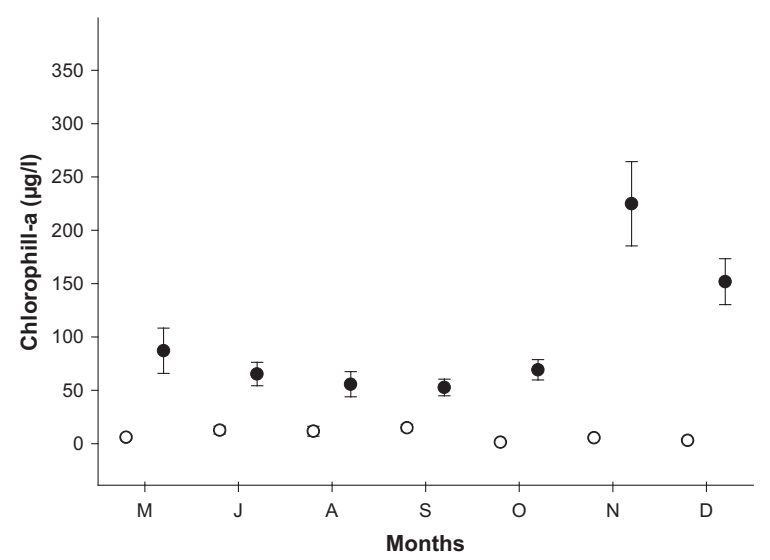

Figure 2. Mean and standard errors of a) turbidity (NTU) and b) chlorophyll- $a$ ( $\mu \mathrm{g} / \mathrm{L})$ in the months of 2008 and 2012. Media $y$ error estándar de a) turbidez (NTU) y b) clorofila-a $(\mu \mathrm{g} / L)$ en los meses de 2008 y 2012.
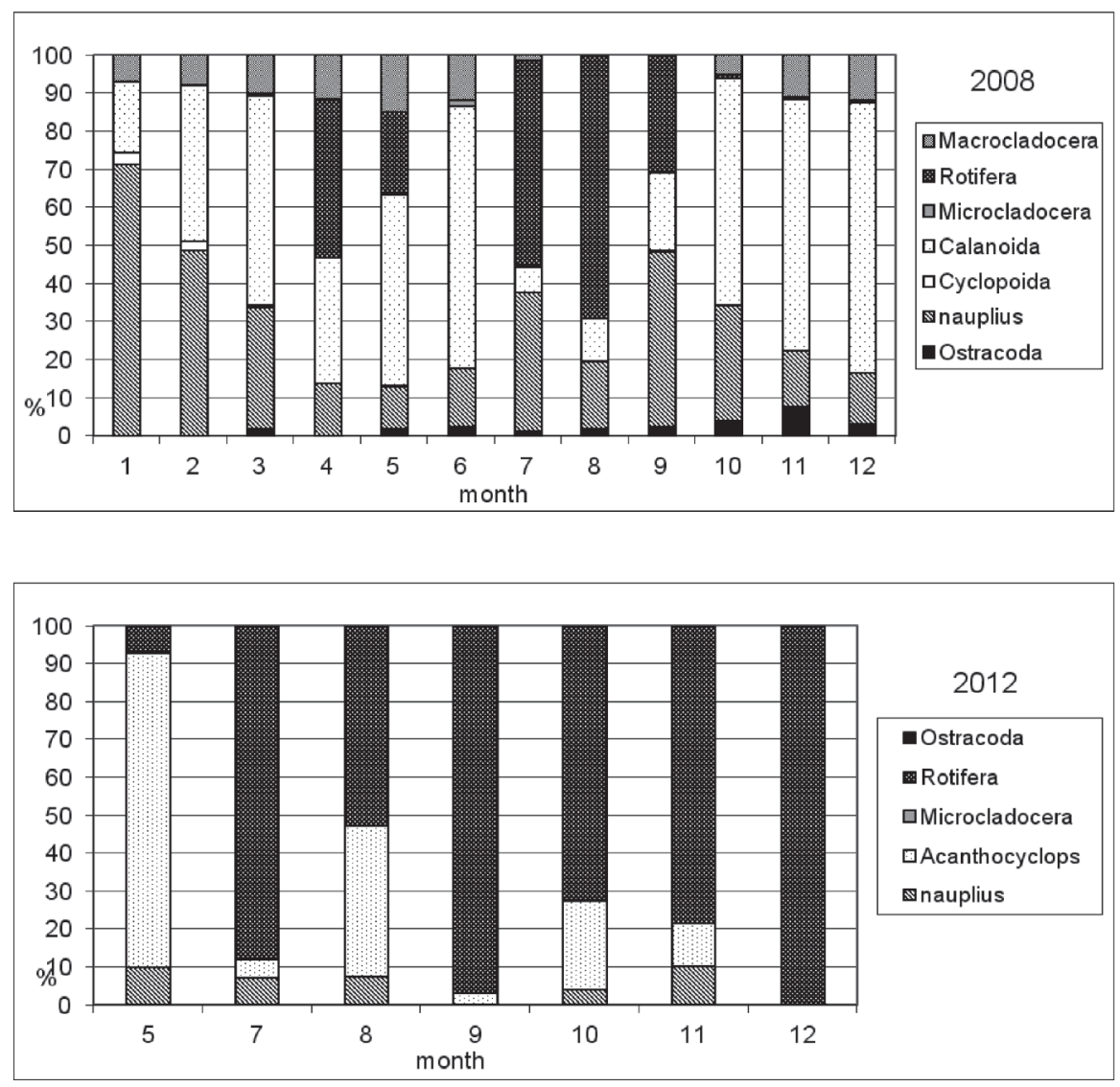

Figure 3. Change of relative abundance of the major zooplankton groups between months in 2008 (without carp) and 2012 (with carp). Acanthocyclops americanus was the only copepod recorded in 2012. Cambio de la abundancia relativa de los principales grupos de zooplancton entre los meses de 2008 (sin carpas) y 2012 (con carpas). Acanthocyclops americanus fue el único copépodo registrado en 2012. 
Table 3. Comparison between 2008 (without carp) and 2012 (with carp) in the number of zooplankton taxa, total number of individuals, Shannon-Wiener diversity $H$ and Evenness $J$. Differences between years were tested with Wilcoxon matched-paired tests, with paired data from the same point and same month (May to December). Comparación entre 2008 (sin carpas) y 2012 (con carpas), entre los diferentes taxones de zooplancton, número total de individuos, diversidad de Shannon-Wiener y uniformidad. $\mathrm{H}$ = diversidad de Shannon-Wiener, $\mathrm{J}=$ uniformidad. Las diferencias entre años fueron evaluadas con un test de Wilcoxon para datos emparejados-pareados, con pares consistentes en los datos para el mismo punto y en el mismo mes (mayo a diciembre).

\begin{tabular}{|c|c|c|c|c|c|c|c|c|}
\hline Month & N Taxa 2008 & N Taxa 2012 & Abundance 2008 & Abundance 2012 & H 2008 & H 2012 & $J 2008$ & J 2012 \\
\hline 5 & 12 & 6 & 16478 & 32606 & 1.391 & 0.5854 & 0.3349 & 0.2993 \\
\hline 7 & 19 & 7 & 18555 & 49535 & 1.426 & 0.4564 & 0.219 & 0.2255 \\
\hline 8 & 15 & 5 & 9121 & 26676 & 1.346 & 0.9212 & 0.256 & 0.5025 \\
\hline 9 & 12 & 6 & 35542 & 187171 & 1.187 & 0.1479 & 0.2731 & 0.1932 \\
\hline 10 & 10 & 5 & 12092 & 77503 & 1.019 & 0.7027 & 0.2771 & 0.4038 \\
\hline 11 & 14 & 6 & 18716 & 62927 & 1.068 & 1.194 & 0.2078 & 0.5498 \\
\hline 12 & 12 & 9 & 8767 & 1548544 & 0.909 & 0.09001 & 0.2068 & 0.1216 \\
\hline$z$ & \multicolumn{2}{|c|}{6.058} & \multicolumn{2}{|c|}{6.334} & \multicolumn{2}{|c|}{3.006} & \multicolumn{2}{|c|}{5.582} \\
\hline$p$ & \multicolumn{2}{|c|}{$<0.0001$} & \multicolumn{2}{|c|}{$<0.0001$} & \multicolumn{2}{|c|}{0.002652} & \multicolumn{2}{|c|}{$<0.0001$} \\
\hline
\end{tabular}

only months sampled in both years, 19 taxa were still recorded in 2008. Almost all taxa showed significant changes in abundance between years, but three of the remaining species increased markedly in abundance in 2012 (Table 2). In 2008, the crustaceans were dominated in abundance by calanoid copepods (Arctodiaptomus salinus) and macrocladocera (Daphnia magna and Moina brachiata) with a relatively high diversity of rotifers (Table 2, Fig. 3). In 2012, calanoid copepods and macrocladoceran species were absent, and the community was dominated by the cyclopoid copepod Acanthocylops americanus and the two rotifer species Brachionus plicatilis and Keratella quadrata (Table 2). The total abundance of rotifers was much higher in 2012 when carp were present (Table 2). With carp, the largest taxa disappeared and there was a loss of size diversity (Fig. 4).

Measures of diversity of the zooplankton communities differed significantly between the two years. Shannon-Wiener diversity was lower in 2012 in all months except November, whereas differences in Evenness changed between months in an inconsistent manner, being higher in 2012 in four of the seven months (Table 3). Overall, Shannon-Wiener diversity was significantly lower and Evenness was significantly higher in 2012.

\section{CCA relating zooplankton with their environment}

According to Canonical Correspondence Analysis (CCA), the two study years are well separated, with abundance values divided along the first and second axes (Fig. 5). The first two axes explain $77.9 \%$ of the total variation in the data set. After 1000 permutations, axis 1 accounted for $57.5 \%$ (eigenvalue: $0.5313, p=0.0001$ ), and axis $220.4 \%$ of variation (eigenvalue: 0.1876, $p=0.001$ ) (Fig. 5.) Total $\mathrm{N}$ and conductivity were positively associated with zooplankton samples from 2008, whereas samples from 2012 were positively associated with dissolved oxygen, chlorophyll- $a$, turbidity, Total $\mathrm{P}$ and total suspended solids (Fig. 5).

\section{Changes in vegetation}

The loss of submerged vegetation in years with carp was obvious but confirmed by remote sensing using Landsat images (Fig. 6). In 2008, macrophytes (mainly Potamogeton pectinatus) filled the water column and were visible at the water surface from May to October inclusive, with a peak cover of $60 \%$. In contrast, no macrophytes were recorded through 2012. 

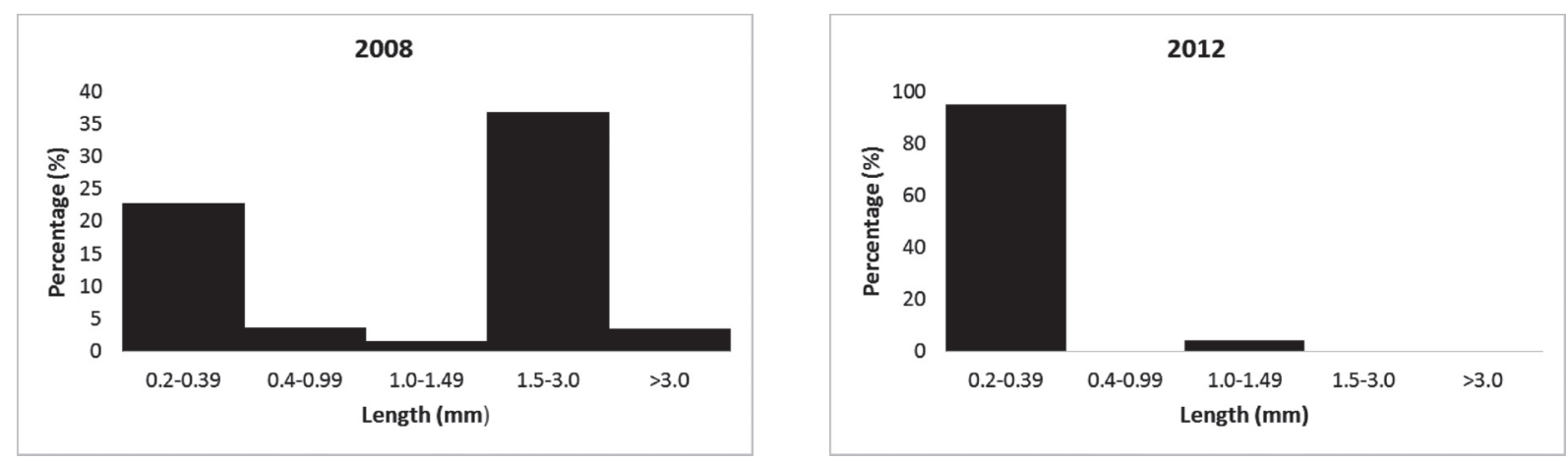

Figure 4. Change in size distribution of the zooplankton between 2008 (without carp) and 2012 (with carp). Based on mean length for each taxon as reported in the literature, and excluding Ostracoda and nauplii larvae. Cambio en la distribución del tamaño del zooplancton entre 2008 ( sin carpas) y 2012 (con carpas). Dependiendo de la longitud media de cada taxón como se informa en la literatura, y excluyendo ostrácodos y larvas nauplio.

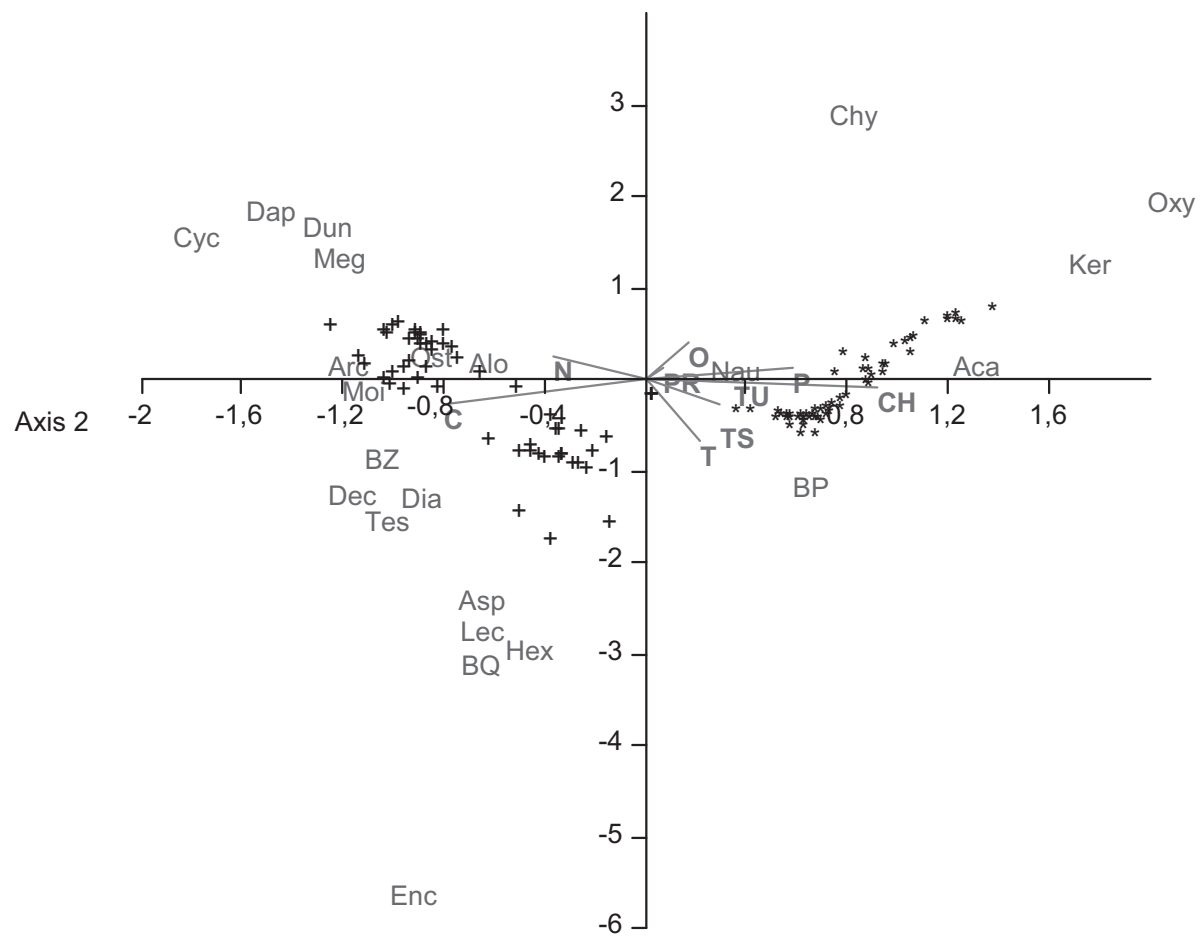

Axis 1

Figure 5. Canonical Correspondence Analysis (CCA) of zooplankton taxa and how they relate to the following environmental variables: $\mathrm{T}=$ temperature. $\mathrm{C}=$ Conductivity. $\mathrm{O}=$ dissolved oxygen. $\mathrm{PR}=$ Depth. $\mathrm{TU}=$ turbidity. $\mathrm{TS}=$ total suspended solids. $\mathrm{CH}=$ chlorophyll- $a . \mathrm{N}=$ total nitrogen. $\mathrm{P}=$ total phosphorus. * indicates samples from 2012 (carp) and + from 2008 (without carp). Análisis de Correspondencia Canónica (CCA) de los taxones de zooplancton y cómo se relacionan con las siguientes variables de entorno: $T$ $=$ temperatura . Con = Conductividad $. O=$ oxígeno disuelto. Prof. $=$ profundidad . Tur $=$ turbidez. TSS $=$ sólidos suspendidos totales . Chlo = clorofila a. $N=$ nitrógeno total. $P=$ fósforo total. $*$ Indica muestras de 2012 (con carpas) y + de 2008 (sin carpas). Taxa are as follows (Los taxones son los siguientes): Aca $=$ Acanthocyclops americanus. Alo = Alona rectangula. Arc $=$ Arctodiaptomus salinus. Asp = Asplachna quadridentatus. $B P=$ Brachionus plicatilis. $B Q=B$. quadridentatus. $B Z=B$. novae-zelandie. Chy $=$ Chydorus pizarri. Dap = Daphnia magna. Dec = Decapoda larvae. Dia = Diaphanosoma brachyura. Dun =Dunhevedia crassa . Enc $=$ Encentrum sp. Hex = Hexarthra fennica. Ker = Keratella quadrata. Lec = Lecane lamellata. Meg = Megacyclops viridis. Moi $=$ Moina brachiata. Nau $=$ nauplius. Ost $=$ Ostracoda. Oxy $=$ Oxyurella tenicaudis. Tes $=$ Testudinella patina . 


\section{DISCUSSION}

\section{Ecological change to a shallow lake after introduction of carp}

The presence of carp in Medina shallow lake has caused a marked increase in phytoplankton biomass (as measured by chlorophyll- $a$ concentration), turbidity and Total P concentration, as well as the loss of submerged macrophytes. These changes represent a marked increase in trophic status (see also de Vicente et al., 2012), and are consistent with repeated observations of the effects of introduced carp elsewhere in Spain (Angeler et al., 2002; Rodrigo et al., 2013) and across several continents (Weber \& Brown, 2009; Kloskowski, 2011; Kulhanek et al., 2011; Fischer et al., 2013; Bajer et al., 2015). Remote sensing has confirmed that these impacts in Medina Lake are consistent over two cycles, with the loss of submerged macrophytes and increase in turbidity in 2004-2007 (first period with carp) and from 2012 until now (second period with carp) (Fig. 6, see also Green et al., 2014). Although these effects of carp are known to depend on their body size and abundance (Nieoczym \& Kloskowski, 2014), unfortunately we have no quantitative data on the age structure and density of carp from Medina.

The increase in Total P we recorded is consistent with the resuspension of sediments in the water column which also contributed to the increased turbidity and TSS (Matsuzaki et al., 2007; Fischer et al., 2013). Phosphorous is bound to the resuspended material (Lougheed $e t$ al., 1998; de Vicente et al., 2012). Earlier studies report increased concentration of Total $\mathrm{N}$ after the introduction of carp (Angeler et al., 2002; Fischer et al., 2013). We found a reduction in Total $\mathrm{N}$ in 2012 with carp, but this is likely to be a direct consequence of the higher water level that year (i.e. a dilution effect caused by the higher levels of precipitation).

Following carp reintroduction, the macrophyte cover of the Lake Medina decreased dramatically (Fig. 6). Loss of macrophytes further enhances the resuspension of sediments owing to wind action, which is important in Medina

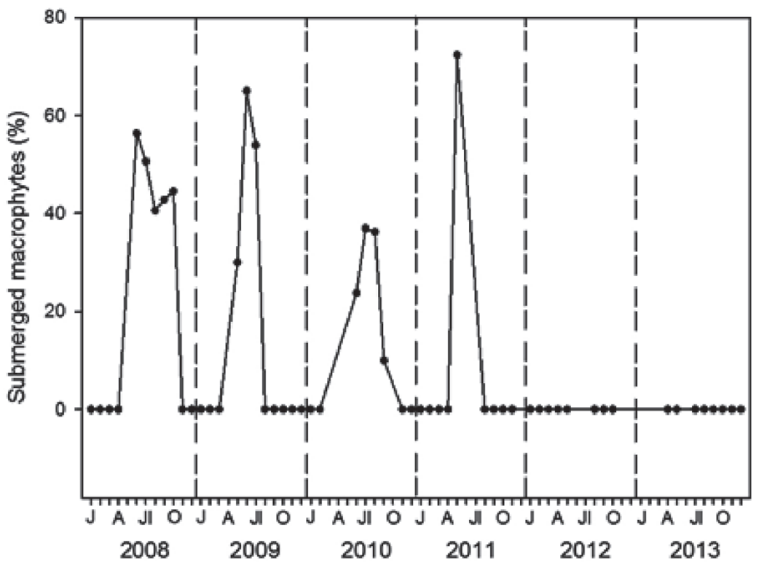

Figure 6. Changes in surface cover of submerged macrophytes between 2008-2010 (without carp) and 2012-2013 (with carp) as detected by remote sensing based on NDVI from Landsat images. Carp entered in the winter of 2010-2011 and were present at low density during 2011. Cambios en la superficie de cobertura de los macrófitos sumergidos en el periodo 20082010 (sin carpas) y 2012-2013 (con carpas) detectadas por teledetección basada en NDVI a partir de imágenes Landsat. Las carpas entraron en el invierno de 2010-2011 y estuvieron presentes en baja densidad durante el año 2011.

lake (de Vicente et al., 2012). The marked increase in chlorophyll- $a$ concentration we recorded is likely due to a combination of the loss of macrophytes, the increase in phosphorus availability and the loss of the large cladocera which are particularly effective filter feeders of phytoplankton (Carpenter 1988; Arnott \& Vanni, 1993).

\section{Impact of carp on zooplankton}

Salinity is a major factor determining community composition in Mediterranean waterbodies, and species richness in zooplankton generally decreases with increasing conductivity (Frisch $e t$ al., 2006; Boix et al, 2008; Waterkeyn et al., 2008). Cladocera are particularly sensitive to high salinities (Green et al., 2005; Badosa et al., 2010). In our case, we found higher species richness when salinity was higher, because the negative impact of carp on zooplankton richness overrode the influence of reduced salinity in 2012. The three species that were dominant in 2012 (Acanthocyclops americanus, Brachionus plicatilis and Keratella quadrata) are all tolerant of a broad range of salinities (Antón-Pardo \& Armengol, 2012) 
and would be likely to be abundant at the lower salinities recorded in 2008 if carp had been present.

As in previous studies (Lougheed et al., 1998; Miller \& Crowl, 2006), in Lake Medina zooplankton taxonomic and size diversity was reduced after carp invasion. The loss of large bodied species such as macrocladocera and Arctodiaptomus and the switch to domination by smaller cyclopoids and rotifers in the presence of carp has been recorded before (Angeler et al., 2002; Matsuzaki et al., 2009). Dominance by Brachionus and Keratella rotifers in the presence of carp was also observed by Fischer et al. (2013). Keratella quadrata is favoured by eutrophic conditions (Xue et al., 2014). Our results are consistent with limited data on zooplankton collected by others at our study site prior to the original carp introduction, which showed that the macrocladocera Moina salina, Daphnia magna and Chydorus pizarri were abundant in 20022003 (Junta de Andalucía, 2005). Large zooplankton species are suppressed by planktivorous fish in general (Brooks \& Dodson, 1965; Jeppesen et al., 1999). The removal of large cladocera which are so effective as filter-feeders promotes the abundance of smaller zooplankton, especially cyclopoid copepods (Arnér et al., 1998) and rotifers (Gilbert, 1988). Cyclopoids have higher fecundity and shorter development time than macrocladocera (Castilho Noll \& Acrifa, 2007), and so can compensate more easily for predation pressure. They also have more effective escape behaviour (Lampert \& Sommer, 1997).

Although carp eat zooplankton (Britton et al., 2007), it is unlikely that predation effects alone explain these changes, and there is experimental evidence that carp prefer copepods to Daphnia (Meijer et al., 1990). We found large copepods such as Megacyclops viridis only without carp. Carp are ecosystem engineers that also affect zooplankton indirectly by creating a hostile environment without submerged macrophytes, and with high concentrations of suspended particles and cyanobacteria. Resuspended particles suppress the growth of large cladocera (Meijer et al., 1990), and turbid-waters are often dominated by rotifers and copepods (Cottenie et al., 2001; Lind, 2003). Macrophytes provide refugia and food for zooplankton and promote species richness for microcrustaceans and rotifers (Lougheed \& Chow-Fraser, 2001; Bagella et al., 2010; Xue et al., 2014). The loss of macrophyte cover is typically followed by a shift towards rotifers and small-bodied zooplankton (Hansen \& Jeppesen, 1992; Hanson \& Butler, 1994) and the release of phytoplankton from top-down control (Schriver et al., 1995).

Cyanobacteria can have a negative effect on macrocladocera (Ferrao-Filho \& KozlowskySuzuki, 2011), and may have contributed to their decline in Medina. Occasional monitoring of phytoplankton by the regional environmental agency suggests a large increase in abundance of cyanobacteria of the orders Chroococcales and Nostocales after the carp invasion. They found that abundance of Chroococcaceae (mainly Chroococcus sp.) increased by roughly three orders of magnitude from $0.72-7.39 \mathrm{ml}^{-1}$ in 2002-2003 (without carp) to $5142 \mathrm{ml}^{-1}$ in 2005 (with carp).

Gambusia holbrooki was present in Medina throughout the study, and also feeds extensively on copepods, cladocerans and rotifers (Cabral et al., 1998). Our results indicate that carp have a much greater impact on the zooplankton community than Gambusia, which are largely confined to the shallow lake edge and are not seen at the depths where we sampled (personal observation). Enclosure experiments have suggested that Gambusia can eliminate cladocerans on their own (Angeler et al., 2002), but our results suggest this is not the case in large, shallow lakes.

\section{Alien copepod with an alien fish}

The only abundant crustacean species in the presence of carp was the pelagic Acanthocylops americanus, which is also associated with eutrophic waterbodies (Miracle et al., 2013). It was introduced from North America to Europe where it was first recorded in the early $20^{\text {th }}$ century, and still appears to be spreading (Alekseev, 1998; Alekseev et al., 2002; Miracle et al., 2013). It is abundant in many lakes and rivers across Europe including Spain, and has been reported from Doñana to the west of Medina lake (Fahd et al., 2009). The dominance of this invasive cyclopoid 
in the presence of alien carp is particularly striking given the near absence of cyclopoids when carp were absent. This apparent association between an alien fish and alien zooplankter may represent a case of facilitation between invasive species, and warrants more investigation. High densities of $A$. americanus have been reported to be associated with high availability of rotifers (Enríquez et al., 2010). The similar A. robustus feeds on rotifers (including Keratella) and even cladocerans, whilst the nauplii feed on phytoplankton (Gliwicz \& Umana, 2004; Enríquez García et al., 2010). Given its dominance, if $A$. americanus had not been introduced to Europe, it is likely that some other native copepod would have been more abundant in the zooplankton community in Medina in 2012. Future research should focus on competitive interactions between this alien copepod and native species.

\section{CONCLUSION}

The monitoring of zooplankton provided a clear measure of the ecological impact of carp in Medina shallow lake. The presence of carp was associated with a radical change in the composition of the zooplankton community and a major reduction in species richness. Given that Gambusia were still present when carp were absent, these changes were greater than those that would be expected on the basis of mesocosm experiments elsewhere. This is probably because of the major transformation from a clear water lake rich in macrophytes, to a turbid lake with abundant phytoplankton caused by carp activity. These bioturbation effects are likely to be particularly acute in Medina lake, owing to the warm Mediterranean temperatures that promote carp activity throughout the annual cycle, as well as the absence of piscivorous fish that can exert top-down control on carp abundance (Bajer et al., 2012).

\section{ACKNOWLEDGMENTS}

The fieldwork and sampling was funded by Ingeniería y Gestión del Sur/IPA, S.L. within the project "Medidas Compensatorias del Embalse de la Breña II". Laboratory analyses were conducted in the Aquatic Ecology Laboratory (LEAEBD). Many people assisted in the fieldwork, especially Anna Badosa and Inma Cintado. Separate monitoring data and data on the biomass of carp removed were provided by the Consejería de Medio Ambiente, Junta de Andalucía. Alberto Maceda-Veiga provided useful comments on an earlier version of the manuscript. NF and LH were supported by a "Research Centre of Excellence- 8526-5/2014/TUDPOL” grant.

\section{REFERENCES}

ALCARAZ-SEGURA, D., J. CABELLO \& J. PARUELO. 2009. Baseline characterization of major Iberian vegetation types based on the NDVI dynamics. Plant Ecology, 202: 13-29.

ALEKSEEV, V. 1998. Key to the freshwater Cyclopoidae of Russia and adjacent lands. Zoosystematica Rossica, 7: 23-43.

ALEKSEEV, V., E. FEFILOVA \& H. J. DUMONT. 2002. Some noteworthy free-living copepods from surface freshwater in Belgium. Belgian Journal of Zoology, 132: 133-139.

AMAT, J. A. 1984. Las poblaciones de aves acuáticas en las lagunas andaluzas: Composición y diversidad durante un ciclo anual. Ardeola, 31: 61-79.

ANDERSON, J.M. 1978. Inter- and intra-habitat relationships between woodland Cryptostigmata species diversity and the diversity of soil and litter microhabitats. Oecologia, 32: 341-348.

ANGELER, D.G., M. ALVAREZ-COBELAS, S. SANCHEZ-CARRILLO \& M. A. RODRIGO. 2002. Assessment of exotic fish impacts on water quality and zooplankton in a degraded semi-arid floodplain wetland. Aquatic Sciences, 64: 76-86.

ANTÓN-PARDO,M. \& X. ARMENGOL. 2012. Effects of salinity and water temporality on zooplankton community in coastal Mediterranean ponds. Estuarine, Coastal and Shelf Science, 114: 93-99.

APHA, A., 1995. Standard methods for the examination of water and wastewater. American Public Health Association. American Water Works Association and Water Environment Federation. 19 ${ }^{\text {th }}$ Edition. Washington D.C. USA. 
ARNÉR, M., S. KOIVISTO, J. NORBERG \& N. KAUTSKY. 1998. Trophic interactions in rockpool food webs: regulation of zooplankton and phytoplankton by Notonecta and Daphnia. Freshwater Biology, 39: 79-90.

ARNOTT, S., E. \& M. J. VANNI. 1993. Zooplankton assemblages in fishless bog lakes: influence of biotic and abiotic factors. Ecology, 74: 2361-2380.

BADOSA, A., D. FRISCH, A. ARECHEDERRA, L. SERRANO \& A. J. GREEN. 2010. Recovery of zooplankton diversity in a restored Mediterranean temporary marsh in Doñana National Park (SW Spain). Hydrobiologia, 654: 67-82.

BAGELLA, S., S. GASCÓN, M. C. CARIA, J. SALA, M. A. MARIANI \& D. BOIX. 2010. Identifying key environmental factors related to plant and crustacean assemblages in Mediterranean temporary ponds. Biodiversity and Conservation, 19: 1749-1768.

BAJER, P. G., G. SULLIVAN \& P. W. SORENSEN. 2009. Effects of rapidly increasing population of common carp on vegetative cover and waterfowl in a recently restored Midwestern shallow lake. Hydrobiologia, 632: 235-245.

BAJER, P.G., C. J. CHIZINSKI, J. J. SILBERNAGEL \& P.W. SORENSEN. 2012. Variation in native micro-predator abundance explains recruitment of a mobile invasive fish, the common carp, in a naturally unstable environment. Biological Invasions, 14: 1919-1929.

BAJER, P. G. \& P. W. SORENSEN. 2015. Effects of common carp on phosphorus concentrations, water clarity, and vegetation density: a whole system experiment in a thermally stratified lake. Hydrobiologia, 746: 303-311.

BOIX, D., S. GASCÓN, J. SALA, A. BADOSA, S. BRUCET, R. LÓPEZ-FLORES, M. MARTINOY, J. GIFRE \& X. D. QUINTANA. 2008. Patterns of composition and species richness of crustaceans and aquatic insects along environmental gradients in Mediterranean water bodies. Hydrobiologia, 597: 53-69.

BRITTON, J. R., R. R. BOAR, J. GREY, J. FOSTER, J. LUGONZO \& D. M. HARPER. 2007. From introduction to fishery dominance: the initial impacts of the invasive carp Cyprinus carpio in Lake Naivasha, Kenya, 1999 to 2006. Journal of Fish Biology, 71: 239-257.

BROOKS, J. L., \& S. I. DODSON. 1965. Predation, body size, and composition of plankton. Science, 150: 28-35.
CABRAL, J. A., C. L. MEIRO \& J. C. MARQUES. 1998. Environmental and biological factors influence the relationships between a predator fish, Gambusia holbrooki, and its main prey in rice fields of the Lower Mondego River Valley (Portugal). Hydrobiologia, 382: 41-51.

CARPENTER, S. R. 1988. Complex Interactions in Lake Communities. Springer-Verlag, New York. USA.

CASTILHO-NOLL, M. S. M. \& M. S. ARCIFA. 2007. Mesocosm experiment on the impact of invertebrate predation on zooplankton of a tropical lake. Aquatic Ecology, 41: 587-598.

COTTENIE, K., N. NUYTTEN, E. MICHELS \& L. DE MEESTER. 2001. Zooplankton community structure and environmental conditions in a set of interconnected ponds. Hydrobiologia, 442: 339-350.

DE VICENTE, I., R. LÓPEZ, I. POZO \& A. J. GREEN. 2012. Nutrient and sediment dynamics in a Mediterranean shallow lake in southwest Spain. Limnetica, 31: 231-250.

DUSSART, B. 1967. Les copépodes des eaux continentales d'Europe Occidentale. I: Calanoïdes et Hapacticoïdes. Editions N. Boubee \& Cie, Paris.

DUSSART, B. 1969. Les copépodes des eaux continentales d'Europe Occidentale. II: Cyclopoïdes et Biologie. Editions N. Boubee \& Cie, Paris.

EINSELE, U. 1993. Süßwasserfauna von Mitteleuropa, Bd. 08/4-1: Crustacea: Copepoda: Calanoida und Cyclopoida, Springer Verlag,

ENRÍQUEZ GARCÍA, C., S. NANDINI \& S. S. S. SARMA. 2010. Demographiccharacteristics of the copepod Acanthocyclops americanus (Sars,1863) (Copepoda: Cyclopoida) fed mixed algal (Scenedesmus acutus)-rotifer (Brachionus havanaensis) diet. Hydrobiologia, 666: 59-69.

FAHD, K., A. ARECHEDERRA, M. FLORENCIO, D. LEON, \& L. SERRANO. 2009. Copepods and branchiopods of temporary ponds in the Doñana Natural Area (SW Spain): a four-decade record (1964-2007). Hydrobiologia, 634: 219-230.

FERRAO-FILHO, A. D. S. \& B. KOZLOWSKYSUZUKI. 2011. Cyanotoxins: bioaccumulation and effects on aquatic animals. Mar. Drugs, 9(12): 2729-2772.

FISCHER, J. R, R. M. KROGMAN \& M. C. QUIST. 2013. Influences of native and non-native benthivorous fishes on aquatic ecosystem degradation. $\mathrm{Hy}$ drobiologia, 711: 187-199. 
FLÖSSNER, D. 2000. Die Haplopoda und Cladocera (ohne Bosminidae) Mitteleuropas. Backhuys Publishers. Leiden. Netherlands.

FRISCH, D., E. MORENO-OSTOS \& A. J. GREEN. 2006. Species richness and distribution of copepods and cladocerans and their relation to hydroperiod and other environmental variables in Doñana, south-west spain. Hydrobiologia, 556: 327-340.

GILBERT, J. J. 1988. Suppression of rotifer populations by Daphnia: A review of the evidence, the mechanisms, and the effects on zooplankton community structure. Limnology and Oceanography, 33: 1286-1303.

GLIWICZ, Z. M. \& G. UMANA. 2004. Cladocera body size and vulnerability to copepod predation. Limnology and Oceanography, 39: 414-424.

GREEN, A. J., C. FUENTES, E. MORENO-OSTOS \& R. DE SILVA. 2005. Factors influencing cladoceran abundance and species richness in brackish lakes in Eastern Spain. Annales de Limnologie-International Journal of Limnology, 41: 73 - 81.

GREEN, A. J., R. LÓPEZ, N. FLORIÁN. 2014. Caracterización limnológica de la Laguna de Medina una respuesta a su restauración. (Informe Técnico) Estación Biológica de Doñana-CSIC. Sevilla. Spain.

GULYÁS, P. \& L. FORRÓ. 1999. Az ágascsápú rákok (Cladocera) kishatározója 2.(bóvített kiadás). Vízi Természet-és Környezetvédelem. Budapest. Hungary.

GULYÁS, P. \& L. FORRÓ. 2001. Az evezólábú rákok (Calanodia ésCyclopoida) alrendjeinek kishatározója 2.(bővitett kiadás), Vízi Természet-és Környezetvédelem. Budapest. Hungary.

HANSEN, A.-M. \& E. JEPPESEN. 1992. Changes in abundance and composition of cyclopoid copepods following fish manipulation in eutrophic Lake Væng, Denmark. Freshwater Biology, 28: 183-193.

HANSON, M. A. \& M. G. BUTLER. 1994. Responses of plankton, turbidity and macrophytes to biomanipulation in a shallow prairie lake. Canadian Journal of Fisheries and Aquatic Sciences, 51: 1180-1188.

JEFFREY, S. W. \& G. F. HUMPHREY. 1975. New spectrophotometric equations for determining chlorophylls a, b, c1 and c2 in higher plants, algae and natural phytoplankton. Biochemie und Physiologie der Pflanzen, 167(19): 191-194.

JEPPESEN, E., J. P. JENSEN, M. SØNDERGAARD \& T. LAURIDSEN. 1999. Trophic dynamics in turbid and clearwater lakes with special emphasis on the role of zooplankton for water clarity. Hydrobiologia 408/409: 217-231.

JUNTA DE ANDALUCÍA. 2005. Caracterización Ambiental de Humedales en Andalucía. Consejería de Medio Ambiente. Sevilla. Spain.

KHAN, T. A. 2003. Dietary studies on exotic carp (Cyprinus carpio L.) from two lakes of western Victoria, Australia. Aquatic Sciences, 65(3): 272286.

KIRK, K. L. \& J. J. GILBERT. 1990. Suspended clay and the population dynamics of planktonic rotifers and cladocerans. Ecology, 71: 1741-1755.

KLOSKOWSKI, J. 2011. Impact of common carp $C y$ prinus carpio on aquatic communities: direct trophic effects versus habitat deterioration. Fundamental and Applied Limnology/Archiv für Hydrobiologie, 178: 245-255.

KOSTE, W. 1978. Rotatoria. Die Rädertiere Mitteleuropas. 2. Tafelband. Gebrüder Borntraeger. Berlin. Germany.

KREBS, C. J. 1989. Ecological Methodology. Harper $\&$ Row. New York. USA.

KULHANEK, S. A., B. LEUNG \& A. RICCIARDI. 2011. Using ecological niche models to predict the abundance and impact of invasive species: application to the common carp. Ecological Applications, 21: 203-213.

LAMPERT, W. \& U. SOMMER. 1997. Limnoecology. Oxford University Press. UK.

LIND, O.T. 2003. Suspended clay's effect on lake and reservoir limnology. Archiv für Hydrobiologie Supplement, 139(3): 327-360.

LOUETTE, G., \& L. DE MEESTER. 2005. High dispersal capacity of cladoceran zooplankton in newly founded communities. Ecology, 86(2): 353-359.

LOUGHEED, V. L., B. CROSBIE \& P. CHOWFRASER. 1998. Predictions on the effect of common carp (Cyprinus carpio) exclusion on water quality, zooplankton and submergent macrophytes in a Great Lakes wetland. Canadian Journal of Fisheries and Aquatic Sciences, 55: 1189-1197.

LOUGHEED, V. L. \& P. CHOW-FRASER. 2001. Spatial variability in the response of lower trophic levels after carp exclusion from a freshwater marsh. Journal of Aquatic Ecosystem Stress and Recovery, 9: 21-34.

MAGURRAN, A. E. 1988. Ecological Diversity and its Measurement. Croom-Helm. London. UK. 
MARTÍ, R. \& J. C. DEL MORAL. 2002. La invernada de aves acuáticas en España. Dirección General de la Naturaleza-SEO/BirdLife, Organismo Autónomo Parques Nacionales. Ministerio de Medio Ambiente. Madrid. Spain.

MARTÍNEZ-HARO, M., A. J. GREEN, P. ACEVEDO \& R. MATEO. 2011. Use of grit supplements by waterbirds: an experimental assessment of strategies to reduce lead poisoning. European Journal of Wildlife Research, 57: 475-484.

MATEO, R., A. J. GREEN, L. LEFRANC, R. BAOS \& J. FIGUEROLA. 2007. Lead poisoning in wild birds from southern Spain: a comparative study of wetland areas and species affected, and trends over time. Ecotoxicology and Environmental Safety, 66: 119-126.

MATHER, P. M. 1987. Computer processing of remotely-sensed images. John Wiley \& Sons. New York. USA.

MATSUZAKI, S. S., N. USIO, N. TAKAMURA \& I. WASHITANI. 2007. Effects of common carp on nutrient dynamics and littoral community composition: roles of excretion and bioturbation. Fundamental and Applied Limnology, 168: 27-38.

MATSUZAKI, S. S., N. USIO, N. TAKAMURA \& I. WASHITANI, 2009. Contrasting impacts of invasive engineers on freshwater ecosystems: an experiment and meta-analysis. Oecologia, 158: 673-686.

MEIJER, M.-L., E. H. R. R. LAMMENS, A. J. P. RAAT, M. P. GRIMM \& S. H. HOSPER. 1990. Impact of cyprinids on zooplankton and algae in ten drainable ponds. Hydrobiologia, 191: 275-284.

MILLER, S. A. \& T. A. CROWL. 2006. Effects of common carp (Cyprinus carpio) on macrophytes and invertebrate communities in a shallow lake. Freshwater Biology, 51: 85-94.

MIRACLE, M. R., V. ALEKSEEV, V. MONCHENKO, V. SENTANDREU \& E. VICENTE. 2013. Molecular-genetic-based contribution to the taxonomy of the Acanthocyclops robustus group. Journal of Natural History, 47: 863-888.

NIEOCZYM, M. \& J. KLOSKOWSKI. 2014. The role of body size in the impact of common carp Cyprinus carpio on water quality, zooplankton, and macrobenthos in ponds. International Review of Hydrobiology, 99: 212-221.

PARKOS, J. J., V. J. SANTUCCI \& D. H. WAHL.
2003. Effects of adult common carp (Cyprinus carpio) on multiple trophic levels in shallow mesocosms. Canadian Journal of Fisheries and Aquatic Sciences, 60: 182-192.

RODRIGO, M. A., C. ROJO, J. L. ALONSO-GUILLÉN, \& P. VERA. 2013. Restoration of two small Mediterranean lagoons: the dynamics of submerged macrophytes and factors that affect the success of revegetation. Ecological Engineering, 54: $1-15$.

RODRÍGUEZ-RODRÍGUEZ, M., A. J. GREEN, R. LÓPEZ \& S. MARTOS-ROSILLO. 2011. Changes in water level, land use, and hydrological budget in a semi-permanent playa lake, southwest Spain. Environmental Monitoring and Assessment, 184(2): 797-810.

SCHRIVER, P., J. BØGESTRAND, E. JEPPESEN \& M. SØNDERGAARD. 1995. Impact of submerged macrophytes on fish-zooplanktonphytoplankton interactions: large-scale enclosure experiments in a shallow eutrophic lake. Freshwater Biology, 33: 255-270.

SIMS, G. K., T. R. ELLSWORTH \& Y. R. L. MULVANEY. 1995. Microscale determination of inorganic nitrogen in water and soil extracts. Coтmunications in Soil Science and Plant Analysis, 26: 303-319.

WATERKEYN, A., P. GRILLAS, B. VANSCHOENWINKEL \& L. BRENDONCK. 2008. Invertebrate community patterns in Mediterranean temporary wetlands along hydroperiod and salinity gradients. Freshwater Biology, 53(9): 1808-1822.

WEBER, M. J. \& M. L. BROWN. 2009. Effects of Common Carp on Aquatic Ecosystems 80 Years after "Carp as a Dominant": Ecological Insights for Fisheries Management. Reviews in Fisheries Science, 17: 524-537.

WILLIAMS, A. E. \& B. MOSS. 2003. Effects of different fish species and biomass on plankton interactions in a shallow lake. Hydrobiologia, 491: 331-346.

XUE, D., F. WEISONG, L. WEI, Y. SHAOWEN, L. JIASHOU, Z. TANGLIN \& L. ZHONGJIE. 2014. Response of rotifer community to environmental changes in five shallow lakes in the middle reach of Changjiang River, China. Chinese Journal of Oceanology and Limnology, 32(5): 1083-1091. 
